\title{
A Study on the impact of Coping Strategies over Stress Management - An Empirical Study
}

\author{
Ch.Narahari ${ }^{\mathrm{a}}$,Dr.KalpanaKoneru ${ }^{\mathrm{b}}$ \\ ${ }^{\mathrm{a}}$ Research Scholar, ; ${ }^{\mathrm{b}}$ Professor\&HoD \\ a, b Department of Management Studies; Vignan's Foundation for Science, Technology and Research; Vadlamudi; Guntur; \\ Andhra Pradesh
}

Article History: Received: 10 November 2020; Revised 12 January 2021 Accepted: 27 January 2021; Published online: 5 April 2021

\begin{abstract}
In the present study we analyze the employees' perception towards coping measures adopted byfirms in software industry. The considered coping constructs adopted for the study in stress abatement areVenting of Emotions,Problem Focused, Seeking Information and emotional support, Positive Emotion-Focused, were, employee perception was acquired by a systematic survey.A total sample of 800 employees'perceptions have been collected through simple random technique and out of which survey respondents, irregular responses are eliminated finally 756 samples are determined for statistical analysis. Chi-square test was performed to determine the association between perceptions and model constructs. Results are reported and discussions are made as per the results and in correlation between results of previous literature.Finally, suggestions and future indication for extension of the study are proposed.
\end{abstract}

Keywords: Stress,Coping Strategies, Stress Management, Empirical Study.

\section{Introduction}

Many researchers look for alternative approaches, including qualitative methods to investigate work stress. Stress measurement may require more than a general agreement that an event takes place at the workplace. With a more qualitative method you can examine the individual assessment of the specific stressful experience in the workplace. This gives a clearer picture of some stress factors that are found in different professions (Narayanan et al., 2020). Although adaptation is recognized as an important mechanism, researchers need a framework for coherence in the existing literature on confrontation (Edwards, 1988, Sivakoti Reddy, M. 2019).

This article presents a conceptual assessment framework that is specifically focused on its approach. The aim is to help researchers select and adapt published adaptation strategies and develop new adaptation strategies. First, it provides a conceptual definition of accommodation that can be used for work stress. We then propose a framework for assessing both the inclusion and specificity of adaptation strategies using confrontational theory and published adaptation strategies (Latack, 2020, Sivakoti Reddy, M. et al., 2019; Addela et al., 2019; Vijaya et al., 2019). Our ultimate goal is to provide order and integration that makes accommodation possible and offers new perspectives on urgent business problems.

\section{Objectives Of The Study:}

- To review the literature with regard to contemporary coping strategies discussed in the literature.

- To empirically analyze the perceptions of employees towards coping measures adopted by organizations for stress abatement.

\section{Literature Review:}

Moos (1992) suggested that coping approaches reflect cognitive and behavioral attempts to control or resolve stressors in life, while avoiding coping outcomes in attempts to reject, relieve or escape from the stressful situation. The women in this study also described approaches to manage their problem approaches using positive judgment or seeking advice and support. (Hall \& Women, 2010). Coping refers to "cognitive and behavioral effortsto master, reduce, or tolerate the internal and/or external demands that are created by a stressful event"(Day $\&$ Livingstone, 2001). 


\section{Coping Measures:}

\section{Problem-focused coping:}

Problem-focused coping is that type of accommodation to solve the stressful situation or event or to change the source of stress. Problem-based coping differs from emotion-based coping, which is about managing emotions associated with the situation rather than changing the situation itself.(Day \& Livingstone, 2001; Lease, 2020; Snow et al., 2003, Sivakoti Reddy et al., 2019, Manukonda et al. 2019)

\section{Emotion-focused coping:}

Emotion-focused coping: It is a type of stress management that attempts to reduce the negative emotional reactions that occur as a result of exposure to stressors. Positive examples include talking or writing about your feelings through therapy or journalism, conscious meditation, or distraction from other activities. It has been explained that managing emotions means recognizing emotions in oneself and in others and being aware of how emotions affect behavior (Day and Livingstone, 2001; Hall and Women, 2010; Snow et al., 2003) . We must be able to respond to emotions correctly. Intense feelings such as anger or sadness can have negative effects on our health if we don't respond properly.

\section{Venting of emotions coping:}

Venting of emotions coping,it refers to stating one's unpleasant feelings or expressing one's negative feelings(Day \& Livingstone, 2001; Hall et al., 2020; Snow et al., 2003). This coping strategy is similar to Explosiveness of speech, one of the characteristics of the Type A behavior pattern.

\section{Research Questions:}

1. Does employee percept that problem focus copingmeasure helps in stress abatement?

2. Does employee percept that Positive emotion-focused copingmeasure helps in stress abatement?

3. Does employee percept that Seeking information and emotional support copingmeasure helps in stress abatement?

4. Does employee percept that Venting of emotions copingmeasure helps in stress abatement?

\section{Hypothesis Formulation:}

H1: Problem focus coping measure positive significantly influences on stress abatement.

H2: Positive emotion-focused coping measure positive significantly influences on stress abatement.

H3: Positive Seeking information and emotional support measure positive significantly influences on stress abatement.

H4: Venting of emotions measure positive significantly influences on stress abatement. 
6.

Proposed Model:

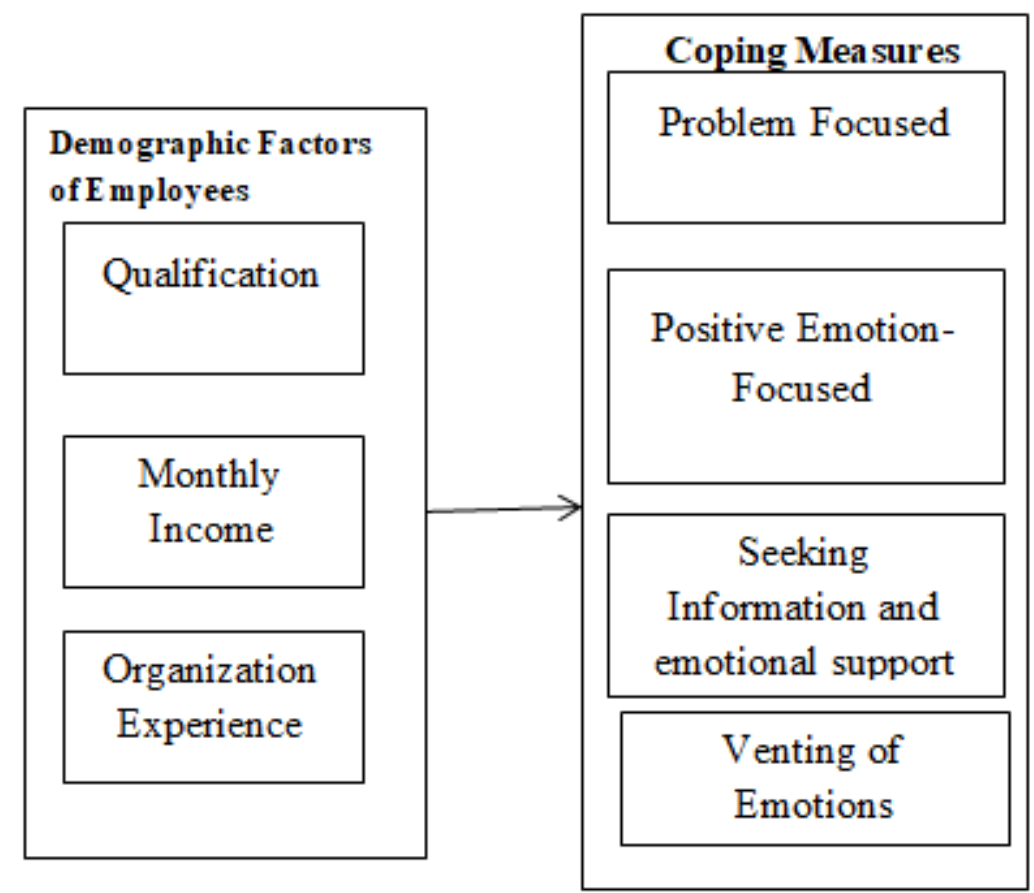

Figure 1Proposed Research Model

\section{Methodology:}

To test the hypothesis the demographic characteristics such as gender, age, marital status, qualification monthly income and experience of employee are cross tabulated towards hypothesized statements and its association was tested using chi-Square test. A total sample of 800 employeesparticipated in the survey study and data was collected through simple random technique and out of which survey respondents' irregular responses are eliminated finally 756 samples are determined for statistical analysis.

\section{Demographics Of The Respondents:}

From the total respondents of 756 employees, about 70.1 percent of the respondents are male and the rest are female. The age factor is most crucial that, about 36.9 percent are under the age of 25-30 years, 40.7 percent of the respondents above 30 years and the rest are under the age category of 20-25 years. With regard to marital status of the employees, about 92.6 percent are married and the rest are unmarried. Such that, about 45.80 percent are under the 2-5 years of experience, 5-10 years' of experience are about 28 percent in the total population. The knowledge levels of the employees matter most that, about 52 percent are postgraduates and about 25.60 percent of the employees possess doctoral degree. The other crucial factor of the respondents, about 52 percent earn between 21,000/- to 30,000/- per month, and only few about 13.60 percnt earn more than 40,000/- per month.

\section{DESCRIPTIVE ANALYSIS: TESTING HYPOTHESIS}

H1: Problem focus coping measure positive significantly influences on stress abatement.

\begin{tabular}{|c|c|c|c|c|c|c|c|c|}
\hline \multicolumn{2}{|c|}{$\begin{array}{l}\text { Demographic } \\
\text { Description }\end{array}$} & $\begin{array}{l}\text { Total } \\
\text { sample } \\
n=756\end{array}$ & $\begin{array}{l}\quad \text { Stron } \\
\text { g } \\
\text { Negative }\end{array}$ & ive $^{\text {Negat }}$ & al Neutr & Positive & $\begin{array}{l}\text { Strong } \\
\text { Positive }\end{array}$ & $\begin{array}{l}\text { Chi- } \\
\text { Square }\end{array}$ \\
\hline \multirow{3}{*}{$\begin{array}{l}\text { Qualific } \\
\text { ation }\end{array}$} & Graduate & 64) $466(61$. & $0(0)$ & $51)^{21(4 .}$ & $41(8.8)$ & $45)^{319(68 .}$ & $24)^{85(18 .}$ & \multirow{3}{*}{$\begin{array}{l}22.2 \\
2,8 \mathrm{df},<0 \\
.05\end{array}$} \\
\hline & $\begin{array}{r}\text { Post- } \\
\text { graduate }\end{array}$ & 33) $252(33$. & 8) $6(2.3$ & $76)^{12(4 .}$ & 3) $21(8.3$ & $32)^{152(60 .}$ & $21)^{61(24 .}$ & \\
\hline & Others & ) $38(5.03$ & $0(0)$ & $0(0)$ & 2) $7(18.4$ & 6) $24(63.1$ & 2) $7(18.4$ & \\
\hline Monthl & Rs. 20,000- & $346(45$. & $2(0.5$ & $11(3$. & $26(7.5$ & $238(68$ & $69(19$. & 24.9 \\
\hline
\end{tabular}




\begin{tabular}{|c|c|c|c|c|c|c|c|c|}
\hline \multirow[t]{4}{*}{ y Income } & 30,000 & 77) & 8) & 18) & 1) & 79) & 94) & \multirow{4}{*}{$\begin{array}{l}9,12 \mathrm{df},< \\
0.05\end{array}$} \\
\hline & $\begin{array}{l}\text { Rs 30,000- } \\
40,000\end{array}$ & $28)^{244(32 .}$ & $0(0)$ & $92)^{12(4 .}$ & $89)^{29(11 .}$ & $52) 155(63$. & $67)^{48(19 .}$ & \\
\hline & $\begin{array}{l}\text { Rs 40,000- } \\
50,000\end{array}$ & $87)^{120(15 .}$ & 3) $4(3.3$ & $33)^{10(8 .}$ & 3) $10(8.3$ & 3) $70(58.3$ & $67)^{26(21 .}$ & \\
\hline & $>$ Rs 50,000 & $46(6.08$ & $0(0)$ & $0(0)$ & $4(8.7)$ & 7) $32(69.5$ & $74)^{10(21 .}$ & \\
\hline \multirow{4}{*}{$\begin{array}{l}\quad \text { Organiz } \\
\text { ation } \\
\text { Experience }\end{array}$} & $0-2$ Years & 77) $278(36$. & $0(0)$ & 8) $8(2.8$ & $07)^{28(10 .}$ & 94) $200(71$. & $11)^{42(15 .}$ & \multirow{4}{*}{$\begin{array}{l}27.9 \\
8,12 \mathrm{df},< \\
0.05\end{array}$} \\
\hline & 2-5 Years & $77)^{346(45 .}$ & 3) $6(1.7$ & $49)^{19(5 .}$ & 6) $31(8.9$ & $72)^{217(62 .}$ & 1) $73(21$. & \\
\hline & 5-10 Years & $62(8.2)$ & $0(0)$ & 5) $4(6.4$ & $2(3.23)$ & 4) $34(54.8$ & $48)^{22(35 .}$ & \\
\hline & $>10$ Years & 70(9.26 & $0(0)$ & 6) $2(2.8$ & 3) $8(11.4$ & 6) $44(62.8$ & $86)^{16(22 .}$ & \\
\hline
\end{tabular}

Table 1: Problem focus coping measure positive significantly influences on stress abatement.

\section{Analysis:}

It can be determined from the contingency table 1 that about 61.6 percent in majority of the employees are graduates and the rest are post-graduates and it is been revealed that qualification of employees has a perceptual significant association with this stress coping measure. It can be analyzed from the contingency table1 that about 45.77 percent in majority of the employees earn Rs.20,000 to Rs.30,000 per month and the rest earn from Rs.30,000 to Rs.50,000 per month and it is been revealed that salary factor of employees has a perceptual significant association with this stress coping measure. It can be understood from the contingency table1 that about 36.77 percent in majority of the employees have less than 2 years of work experience and rest ranges from 5 years to 10 years and it is been revealed that professional experience of employees has a perceptual significant association with this stress coping measure.

H2: Positive emotion-focused coping measure positive significantly influences on stress abatement.

\begin{tabular}{|c|c|c|c|c|c|c|c|c|}
\hline \multicolumn{2}{|c|}{$\begin{array}{l}\text { Demographic } \\
\text { Description }\end{array}$} & \multirow{2}{*}{$\begin{array}{l}\begin{array}{l}\text { Total } \\
\text { sample } \\
\mathbf{n}=\mathbf{7 5 6}\end{array} \\
\frac{1}{466(61 .}\end{array}$} & \multirow{2}{*}{$\begin{array}{l}\text { Stron } \\
\text { g } \\
\text { Negative }\end{array}$} & \multirow{2}{*}{$\begin{array}{l}\text { ive }^{\text {Negat }} \\
\frac{22)^{15(3 .}}{}\end{array}$} & \multirow{2}{*}{$\begin{array}{l}\text { al Neutr } \\
\frac{23)^{57(12 .}}{}\end{array}$} & \multirow{2}{*}{$\begin{array}{r}\text { Positive } \\
74)^{311(66 .}\end{array}$} & \multirow{2}{*}{$\begin{array}{l}\begin{array}{c}\text { Strong } \\
\text { Positive }\end{array} \\
9^{79(16 .}\end{array}$} & \multirow{2}{*}{$\begin{array}{l}\quad \text { Chi } \\
- \\
\text { Squar } \\
\text { e }\end{array}$} \\
\hline \multirow{3}{*}{$\begin{array}{l}\text { Quali } \\
\text { fication }\end{array}$} & Graduate & & & & & & & \\
\hline & $\begin{array}{r}\text { Post- } \\
\text { graduate }\end{array}$ & $33)^{252(33 .}$ & 9) $2(0.7$ & 7) $8(3.1$ & 2) $25(9.9$ & 3) $157(62$. & $81)^{60(23 .}$ & \multirow[t]{2}{*}{$\begin{array}{l}\quad 7.1 \\
8,8 \mathrm{df},> \\
0.05\end{array}$} \\
\hline & Others & $38(5.03$ & $0(0)$ & $0(0)$ & 6) $5(13.1$ & 6) $24(63.1$ & 8) $9(23.6$ & \\
\hline \multirow{4}{*}{$\begin{array}{l}\text { Mont } \\
\text { hly } \\
\text { Income }\end{array}$} & $\begin{array}{c}\text { Rs. } \\
20,000- \\
30,000\end{array}$ & $77)^{346(45 .}$ & $0(0)$ & $76)^{13(3 .}$ & 3) $34(9.8$ & $63)^{234(67 .}$ & $79)^{65(18 .}$ & \multirow{4}{*}{$\begin{array}{r}12 . \\
82,12 d \\
f,>0.05\end{array}$} \\
\hline & $\begin{array}{c}\text { Rs } \\
30,000- \\
40,000\end{array}$ & $28)^{244(32 .}$ & 4) $4(1.6$ & $6)^{6(2.4}$ & 7) $31(12$. & $11)=$ & $08)^{49(20 .}$ & \\
\hline & $\begin{array}{c}\text { Rs } \\
40,000- \\
50,000\end{array}$ & $87)^{120(15 .}$ & 7) $2(1.6$ & $3)^{4(3.3}$ & $18(15)$ & $72(60)$ & $24(20)$ & \\
\hline & $>$ Rs50,00 & $46(6.08$ & $0(0)$ & $0(0)$ & $4(8.7)$ & $32(69.5$ & $10(21$. & \\
\hline
\end{tabular}




\begin{tabular}{|c|c|c|c|c|c|c|c|c|}
\hline & 0 & ) & & & & 7) & 74) & \\
\hline \multirow{4}{*}{$\begin{array}{l}\quad \text { Orga } \\
\text { nization } \\
\text { Experien } \\
\text { ce }\end{array}$} & 0-2 Years & ${ }_{77)}^{278(36 .}$ & $0(0)$ & $6)^{6(2.1}$ & $39)^{40(14 .}$ & $42)^{193(69 .}$ & $03)^{39(14 .}$ & \multirow{4}{*}{$\begin{array}{r}25 . \\
91,12 \mathrm{~d} \\
\mathrm{f},<0.05\end{array}$} \\
\hline & 2-5 Years & $77)^{346(45 .}$ & 3) $6(1.7$ & $76)^{13(3 .}$ & $27)^{39(11 .}$ & $98)^{211(60 .}$ & $25)^{77(22 .}$ & \\
\hline & $\begin{array}{l}5-10 \\
\text { Years }\end{array}$ & $62(8.2)$ & $0(0)$ & 3) $2(3.2$ & $2(3.23)$ & 9) $46(74.1$ & $35)^{12(19 .}$ & \\
\hline & $\begin{array}{cc}> & 10 \\
\text { Years } & \end{array}$ & $\begin{array}{l}70(9.26 \\
\end{array}$ & $0(0)$ & 6) $2(2.8$ & $6(8.57)$ & $42(60)$ & ${ }_{57)}^{20(28 .}$ & \\
\hline
\end{tabular}

Table 2: Positive emotion-focused coping measure positive significantly influences on stress abatement.

\section{Analysis:}

It can be determined from the contingency table1 that about 61.64 percent in majority of the employees are graduates and the rest are post-graduates and it is been revealed that qualification of employees has no perceptual significant association with this stress coping measure. It can be analyzed from the contingency table1 that about 45.77 percent in majority of the employees earn Rs.20,000 to Rs.30,000 per month and the rest earn from Rs.30,000 to Rs.50,000 per month and it is been revealed that salary factor of employees has no perceptual significant association with this stress coping measure. It can be understood from the contingency table 1 that about 36.77 percent in majority of the employees have less than 2 years of work experience and rest ranges from 5 years to 10 years and it is been revealed that professional experience of employees has a perceptual significant association with this stress coping measure.

H3: Positive Seeking information and emotional support measure positive significantly influences on stress abatement.

\begin{tabular}{|c|c|c|c|c|c|c|c|c|}
\hline \multicolumn{2}{|c|}{ Demographic Description } & \multirow{2}{*}{\begin{tabular}{l}
\multicolumn{1}{c}{\begin{tabular}{c}
\multicolumn{1}{c}{ Total } \\
sample \\
$\mathbf{n = 7 5 6}$
\end{tabular}} \\
\multicolumn{1}{c}{$466(61}$. \\
$64)^{4}$
\end{tabular}} & \multirow{2}{*}{$\begin{array}{l}\text { Stron } \\
\text { g } \\
\text { Negative } \\
3)^{2(0.4}\end{array}$} & \multirow{2}{*}{$\begin{array}{l}\text { ive }^{\text {Negat }} \\
\text { 9) }^{6(1.2}\end{array}$} & \multirow{2}{*}{$\begin{array}{l}\text { al }^{\text {Neutr }} \\
\left.{ }^{49(10}\right)^{49}\end{array}$} & \multirow{2}{*}{$\begin{array}{c}\text { e }^{\text {Positiv }} \\
.68)^{348(74}\end{array}$} & \multirow{2}{*}{$\begin{array}{l}\text { Stron } \\
\text { g } \\
\text { Positive } \\
61(13 \\
.09)\end{array}$} & \multirow{3}{*}{$\begin{array}{c}\begin{array}{c}\text { Chi- } \\
\text { Square }\end{array} \\
\\
4.82,8 \mathrm{df}, \\
>0.05\end{array}$} \\
\hline \multirow{3}{*}{$\mathrm{n}$} & Graduate & & & & & & & \\
\hline & $\begin{array}{r}\text { Post- } \\
\text { graduate }\end{array}$ & $33)^{252(33 .}$ & $0(0)$ & 9) $4(1.5$ & $92)^{25(9 .}$ & $\begin{array}{l}187(74 \\
.21)^{18}\end{array}$ & $\begin{array}{l}36(14 \\
.29)^{36}\end{array}$ & \\
\hline & Others & $38(5.03$ & $0(0)$ & $0(0)$ & $42)^{7(18 .}$ & $79)^{25(65 .}$ & $79)^{6(15 .}$ & \\
\hline \multirow{4}{*}{$\begin{array}{l}\text { Monthly } \\
\text { Income }\end{array}$} & $\begin{array}{c}\text { Rs. } \\
20,000- \\
30,000\end{array}$ & $77)^{346(45 .}$ & $0(0)$ & $8)^{2(0.5}$ & $.98)^{38(10}$ & $.43)^{261(75}$ & $.01)^{45(13}$ & \multirow{4}{*}{$\begin{array}{l}10.01,12 \\
\mathrm{df},>0.05\end{array}$} \\
\hline & $\begin{array}{l}\text { Rs } \\
30,000- \\
40,000\end{array}$ & $28)^{244(32 .}$ & $2(0.8$ & $6)^{6(2.4}$ & $.25)^{25(10}$ & $\begin{array}{l}.54)^{177(72} \\
.\end{array}$ & $.93)^{34(13}$ & \\
\hline & $\begin{array}{c}\mathrm{Rs} \\
40,000- \\
50,000\end{array}$ & $87)^{120(15 .}$ & $0(0)$ & 7) $2(1.6$ & ) $12(10$ & $90(75)$ & $.33)^{16(13}$ & \\
\hline & $\begin{array}{r}>\mathrm{Rs} \\
50,000\end{array}$ & $46(6.08$ & $0(0)$ & $0(0)$ & $04)^{6(13 .}$ & $57)^{32(69 .}$ & $39)^{8(17 .}$ & \\
\hline \multirow{3}{*}{$\begin{array}{l}\text { Organizatio } \\
\text { n Experience }\end{array}$} & 0-2 Years & $\begin{array}{l}278(36 . \\
77)\end{array}$ & $0(0)$ & 2) $2(0.7$ & $.23)^{34(12}$ & $\begin{array}{l}215(77 \\
.34)^{2}\end{array}$ & $71)^{27(9 .}$ & \multirow{3}{*}{$\begin{array}{r}16.01,12 \\
\mathrm{df},>0.05\end{array}$} \\
\hline & 2-5 Years & $77)^{346(45 .}$ & $8)^{2(0.5}$ & 3) $6(1.7$ & $\begin{array}{l}37(10 \\
.69)^{37}\end{array}$ & $\begin{array}{l}247(71 \\
.39)^{2}\end{array}$ &.$^{54(15}$ & \\
\hline & $5-10$ & $62(8.2)$ & $0(0)$ & $2(3.2$ & $2(3.2$ & $48(77$ & $10(16$ & \\
\hline
\end{tabular}




\begin{tabular}{|ll|l|l|l|l|l|l|} 
Years & & & $3)$ & $3)$ & $42)$ & $.13)$ \\
\hline $\begin{array}{c}> \\
\text { Years }\end{array}$ & 10 & $70(9.26$ & $0(0)$ & $0(0)$ & $43)$ & $43)$ & \multicolumn{1}{|l|}{$8(11}$. \\
\hline
\end{tabular}

Table 3:Positive Seeking information and emotional support measure positive significantly influences on stress abatement.

\section{Analysis:}

It can be determined from the contingency table 1 that about 61.64 percent in majority of the employees are graduates and the rest are post-graduates and it is been revealed that qualification of employees has no perceptual significant association with this stress coping measure. It can be analyzed from the contingency table1 that about 45.77 percent in majority of the employees earn Rs.20,000 to Rs.30,000 per month and the rest earn from Rs.30,000 to Rs.50,000 per month and it is been revealed that salary factor of employees has no perceptual significant association with this stress coping measure. It can be understood from the contingency table 1 that about 36.77 percent in majority of the employees have less than 2 years of work experience and rest ranges from 5 years to 10 years and it is been revealed that professional experience of employees has no perceptual significant association with this stress coping measure.

H4: Venting of emotions measure positive significantly influences on stress abatement.

\begin{tabular}{|c|c|c|c|c|c|c|c|c|}
\hline \multicolumn{2}{|c|}{$\begin{array}{l}\text { Demographic } \\
\text { Description }\end{array}$} & \multirow{2}{*}{$\begin{array}{l}\begin{array}{c}\text { Total } \\
\text { sample } \\
\mathbf{n}=756\end{array} \\
\frac{466(61 .}{64)}\end{array}$} & \multirow{2}{*}{$\begin{array}{l}\text { Stron } \\
\text { g } \\
\text { Negative } \\
3)^{2(0.4}\end{array}$} & \multirow{2}{*}{$\frac{\text { ive }^{\text {Negat }}}{08)^{19(4 .}}$} & \multirow{2}{*}{$\frac{\text { al Neutr }}{94)^{51(10 .}}$} & \multirow{2}{*}{$\begin{array}{r}\text { Positive } \\
31)^{323(69 .}\end{array}$} & \multirow{2}{*}{$\begin{array}{l}\begin{array}{r}\text { Strong } \\
\text { Positive }\end{array} \\
\frac{24)^{71(15 .}}{}\end{array}$} & \multirow{3}{*}{$\begin{array}{l}\begin{array}{r}\text { Chi- } \\
\text { Square }\end{array} \\
\\
\\
\quad 9.57, \\
\text { df } 8,<0.0 \\
5\end{array}$} \\
\hline \multirow{3}{*}{$\begin{array}{l}\text { Qualifi } \\
\text { cation }\end{array}$} & $\mathrm{e}^{\text {Graduat }}$ & & & & & & & \\
\hline & $\begin{array}{r}\text { Post- } \\
\text { graduate }\end{array}$ & $33)^{252(33 .}$ & 9) $2(0.7$ & 7) $8(3.1$ & 2) $25(9.9$ & $48)^{165(65 .}$ & $63)^{52(20 .}$ & \\
\hline & Others & $38(5.03$ & $0(0)$ & $0(0)$ & 5) $8(21.0$ & 3) $23(60.5$ & 2) $7(18.4$ & \\
\hline \multirow{4}{*}{$\begin{array}{l}\text { Monthl } \\
\text { y Income }\end{array}$} & $\begin{array}{c}\text { Rs. } \\
20,000- \\
30,000\end{array}$ & $77)^{346(45 .}$ & $0(0)$ & $76)^{13(3 .}$ & $69)^{37(10 .}$ & $23)^{243(70 .}$ & $32)^{53(15 .}$ & \multirow{4}{*}{$\begin{array}{l}\quad 10.4 \\
3, \text { df } 12,< \\
0.05\end{array}$} \\
\hline & \begin{tabular}{l}
\multicolumn{1}{c}{$\mathrm{Rs}$} \\
$30,000-$ \\
40,000
\end{tabular} & $28)^{244(32 .}$ & $2)^{2(0.8}$ & $8)^{8(3.2}$ & $89)^{29(11 .}$ & $75)^{158(64 .}$ & $26)^{47(19 .}$ & \\
\hline & $\begin{array}{c}\text { Rs } \\
40,000- \\
50,000\end{array}$ & $87) 120(15$. & 7) $2(1.6$ & $6(5)$ & $12(10)$ & $78(65)$ & $33) 22(18$. & \\
\hline & $\begin{array}{r}>\mathrm{Rs} \\
50,000\end{array}$ & ) $46(6.08$ & $0(0)$ & $0(0)$ & 4) $6(13.0$ & 7) $32(69.5$ & 9) $8(17.3$ & \\
\hline \multirow{4}{*}{$\begin{array}{l}\qquad \text { Organiz } \\
\text { ation } \\
\text { Experience }\end{array}$} & $\begin{array}{l}0-2 \\
\text { Years }\end{array}$ & $77)^{278(36 .}$ & $0(0)$ & 6) $10(3$. & $51)^{32(11 .}$ & $66)^{202(72 .}$ & $23)^{34(12 .}$ & \multirow{4}{*}{$\begin{array}{l}18.1 \\
8, \text { df } 12,< \\
0.05\end{array}$} \\
\hline & $\begin{array}{l}2-5 \\
\text { Years }\end{array}$ & $77)^{346(45 .}$ & 6) $4(1.1$ & $34)^{15(4 .}$ & $98)^{38(10 .}$ & $87)^{221(63 .}$ & $65)^{68(19 .}$ & \\
\hline & $\begin{array}{l}5-10 \\
\text { Years }\end{array}$ & $62(8.2)$ & $0(0)$ & $0(0)$ & $4(6.45)$ & 7) $44(70.9$ & $58)^{14(22 .}$ & \\
\hline & $\begin{array}{cc}> & 10 \\
\text { Years } & \end{array}$ & $70(9.26$ & $0(0)$ & 6) $2(2.8$ & $29)^{10(14 .}$ & 6) $44(62.8$ & $14(20)$ & \\
\hline
\end{tabular}

Table 4: Venting of emotions measure positive significantly influences on stress abatement. 


\section{Analysis:}

It can be determined from the contingency table1 that about 61.64 percent in majority of the employees are graduates and the rest are post-graduates and it is been revealed that qualification of employees has a perceptual significant association with this stress coping measure. It can be analyzed from the contingency table 1 that about 45.77 percent in majority of the employees earn Rs.20,000 to Rs.30,000 per month and the rest earn from Rs.30,000 to Rs.50,000 per month and it is been revealed that salary factor of employees has a perceptual significant association with this stress coping measure. It can be understood from the contingency table 1 that about 36.77 percent in majority of the employees have less than 2 years of work experience and rest ranges from 5 years to 10 years and it is been revealed that professional experience of employees has a perceptual significant association with this stress coping measure.

\section{Results And Discussions:}

It can be determined from the contingency table 1 that about 61.6 percent in majority of the employees are graduates and the rest are post-graduates and it is been revealed that qualification of employees has a perceptual significant association with this stress coping measure, hence H1 is proved.It can be determined from the contingency table1 that about 61.64 percent in majority of the employees are graduates and the rest are postgraduates and it is been revealed that qualification of employees has no perceptual significant association with this stress coping measure,hence $\mathrm{H} 2$ is proved.It can be understood from the contingency table1 that about 36.77 percent in majority of the employees have less than 2 years of work experience and rest ranges from 5 years to 10 years and it is been revealed that professional experience of employees has no perceptual significant association with this stress coping measure, hence $\mathrm{H} 3$ is disproved.It can be understood from the contingency table 1 that about 36.77 percent in majority of the employees have less than 2 years of work experience and rest ranges from 5 years to 10 years and it is been revealed that professional experience of employees has a perceptual significant association with this stress coping measure, hence $\mathrm{H} 4$ is proved.

\section{References}

Day, A. L., \& Livingstone, H. A. (2001). Chronic and Acute Stressors Among Military Personnel : Do Coping Styles Buffer Their Negative Impact on Health? Journal of Occupational Health Psychology, 6(4). https://doi.org/10.1037//1076-8998.6.4.348

Hall, J. C., Everett, J. E., \& Hamilton-mason, J. (2020). Linked references are available on JSTOR for this article: Stress and How About Workplace They Cope. Journal of Black Studies, 43(2), $207-226$. https://doi.org/10.1177/0021934711413272

Hall, J. C., \& Women, B. (2010). Everyday Conflict and Daily Stressors : Coping Responses of Black Women Everyday Conflict and Daily Stressors: Coping Responses of. Journal of Women and Social Work. https://doi.org/10.1177/0886109909354983

Latack, J. C. (2020). Coping with Job Stress : A Conceptual Evaluation Framework for Coping Measures. JOURNAL OF ORGANIZATIONAL BEHAVIOR, 13(5), 479-508.

Lease, S. H. (2020). Occupational Role Stressors , Coping, Support, and Hardiness as Predictors of Strain in Academic Faculty: An Emphasis on New and Female Faculty Author ( s ): Suzanne H . Lease Source : Research in Higher Education, Vol . 40 , No . 3 ( Jun ., 1999 ), p. Research in Higher Education, 40(3), 285-307.

Moos, R. (1992). Stress and coping theory and evaluation research: An integrated perspective. Evaluation Review, 16, 534-553.

Narayanan, L., Menon, S., Spector, P. E., Journal, S., \& Jan, N. (2020). Stress in the Workplace : A Comparison of Gender and Occupations Linked references are available on JSTOR for this article : Stress in the workplace : a comparison of gender and occupations. Journal of Organizational Behavior, 20(1), 63-73.

Snow, D. L., Swan, S. C., Raghavan, C., Connell, C. M., \& Klein, I. (2003). The relationship of work stressors , coping and social support to psychological symptoms among female secretarial employees. Work \& Stress, September.https://doi.org/10.1080/02678370310001625630

Sivakoti Reddy, M. (2019). Impact of RSERVQUAL on customer satisfaction: A comparative analysis between traditional and multi-channel retailing. International Journal of Recent Technology and Engineering. 8(1), pp. 2917-2920.

Sivakoti Reddy, M., Murali Krishna, S.M. (2019). Influential role of retail service quality in food and grocery retailing: A comparative study between traditional and multi-channel retailing. International Journal of Management and Business Research, 2019, 9(2), pp. 68-73

Sivakoti Reddy, M., Venkateswarlu, N. (2019). Customer relationship management practices and their impact over customer purchase decisions: A study on the selected private sector banks housing finance schemes. International Journal of Innovative Technology and Exploring Engineering, 2019, 8(7), pp. 1720-1728.

Addela, S., Sivakoti Reddy, M. (2019).Mobile banking-an empirical analysis on the customer's perception towards mobile banking in determining the customer satisfaction in the state of telangana rural areas. Journal of Advanced Research in Dynamical and Control Systems, 2019, 11(6), pp. 318-321 
Vijaya, P., Sivakoti Reddy, M. (2019). A study on the moderating role of trust in determining the green purchase intentions: Empirical evidence from Indian automobile sector. Journal of Advanced Research in Dynamical and Control Systems, 2019, 11(11), pp. 39-47.

Sivakoti Reddy, M., Naga Bhaskar, M., Nagabhushan, A.(2019). Saga of silicon plate: An empirical analysis on the impact of socio economic factors of farmers on inception of solar plants. International Journal of Control Theory and Applications, 2016, 9(29), pp. 257-266.

Manukonda et al. (2019). What Motivates Students To Attend Guest Lectures?.The International Journal of Learning in Higher Education. Volume 26, Issue 1. 23-34. 